\title{
LABORATORY-SCALE PRODUCTION OF ADU GELS BY EXTERNAL GELATION FOR AN INTERMEDIATE HTGR NUCLEAR
}

\author{
S. Simbolon and S.R Susilowati \\ Center for Accelerator Science and Technology - BATAN \\ Jl.Babarsari No.2, P.O. Box 6101 ykbb, Yogyakarta, Indonesia \\ e-mail: simbolon@batan.go.id \\ (Naskah diterima : 5-12-2014, Naskah direvisi: 21-01-2015, Naskah disetujui: 26-01-2015)
}

\begin{abstract}
LABORATORY-SCALE PRODUCTION OF ADU GELS BY EXTERNAL GELATION FOR AN INTERMEDIATE HTGR NUCLEAR. The The aim of this research is to produce thousands of microsphere ADU (Ammonium Diuranate) gels by using external gelation for an intermediate HTGR (High Temperature Gas-cooled Reactor) nuclear fuel in laboratory-scale. Microsphere ADU gels were based on sol-solution which was made from a homogeneous mixture of ADUN (Acid Deficient Uranyl Nitrate) which was containing uranyl ion in high concentration, a water soluble organic compound PVA (Polyvinyl Alcohol) and THFA (Tetrahydrofurfuryl Alcohol). The simple unified home made laboratory experimental machine was developed to replace test tube experiment method which was once used due to a tiny amount of microsphere ADU gels produced. It consists of four main parts: tank filled sol-solution connecting to peristaltic pump and vibrating nozzle, preliminary gelation and gelation column. The machine has successfully converted $150 \mathrm{~mL}$ sol-solution into thousands of drops which produced 120 - 130 drops in each minute in steady state in ammonia gas free sector. Preliminary gelation reaction was carried out in ammonia gas sector where drops react with ammonia gas in a bat an eye followed by gelation reaction in column containing ammonia solution $7 \mathrm{M}$. In ageing process, ADU gels were collected and submerged into a vessel containing ammonia solution which was shaken for 1 hour in a shaker device. Isopropyl alcohol (90\%) solution was used to wash ADU gels and a digital camera was used to measured spherical form of ADU gels. Diameters in spherical spheroid form were found between $1.8 \mathrm{~mm}$ until $2.2 \mathrm{~mm}$. The spherical purity of ADU gels were $10 \%-20 \%$ others were oblate, prolate spheroid and microsphere which have hugetiny of dimples on the surface.
\end{abstract}

Keywords : ADUN, sol-solution, ADU-gels, gelation, spherical pheroid.

\begin{abstract}
ABSTRAK
PRODUKSI GEL ADU SKALA LABORATORIUM DENGAN MENGGUNAKAN GELASI EKSTERNAL UNTUK BAHAN BAKAR ANTARA HTGR. Penelitian ini bertujuan untuk membuat ribuan gel bulat ADU (Ammonium Diuranate) dengan menggunakan gelasi ekternal untuk bahan bakar nuklir HTGR (High Temperature Gas-cooled Reactor) menengah untuk skala laboratorium. Gel bulat ADU dibuat berbasis pada larutan-sol yang dibentuk dari campuran homogen ADUN (Acid Deficient Uranyl Nitrate) yang mengandung ion uranil dengan konsentrasi sangat tinggi, larutan PVA (Polyvinyl Alcohol) dan THFA (Tetrahydrofurfuryl Alcohol). Perangkat laboratorium untuk eksperimen dikembangkan untuk menggantikan metode eksperimen tabung pengujian yang telah digunakan untuk menghasilkan sejumlah gel bulat ADU. Perangkat tersebut terdiri atas empat bagian utama: tangki yang berisi larutan-sol yang terhubung dengan pompa peristaltik dan nosel vibrasi, gelasi awal dan kolom gelasi. Perangkat tersebut telah berhasil mengubah $150 \mathrm{~mL}$ larutansol menjadi ribuan tetes dengan produksinya berkisar 120-130 tetesan tiap menit dengan kondisi
\end{abstract}


tunak dalam sektor yang bebas gas ammonia. Reaksi awal gelasi dilakukan di sektor gas ammonia dimana tetesan bereaksi dengan gas amonia yang diikuti dengan reaksi gelasi di dalam kolom yang mengandung larutan ammonia $7 \mathrm{M}$. Dalam proses penuaan, gel ADU ditampung dan direndam dengan larutan ammonia yang digoyang selama 1 jam. Larutan isopropyl alkohol (90\%) digunakan untuk mencuci gel ADU dan kamera digital digunakan untuk mengukur kebulatan gel ADU. Diameter dari bentuk bulat bola berkisar antara $1.8 \mathrm{~mm}$ hingga $2.2 \mathrm{~mm}$. kebulatan gel ADU selama produksi berkisar $10 \%$ - 20\%, selain itu berbentuk bola oblate, prolate dan ada cekungan pada permukaan.

Kata Kunci: ADUN, larutan-sol, Gel ADU, gelasi, bulat bola

\section{INTRODUCTION}

For more than a decade researchers in PSTA (Center for Accelerator Science and Technology, previously PTAPB, Center for Accelerator and Material Process Technology), have studied nuclear fuel through sol-gel technique, based on either internal or external method, both of them were carried out in test tube experiment scale ${ }^{[1]}$. It was therefore decided to modify and to improve the character and abundance of ammonium diuranate (ADU) gels by external method because it is relatively easy to prepare, stability of solution and fast gelation reaction. In external gelation, the ammonia is transferred from external source. A precursor solution is Acid Deficient Uranyl Nitrate (ADUN) solution which is the most important of feed solution and it is prepared by pre-neutralization process ${ }^{[2,3]}$

A simple unified home made laboratory experimental machine was developed which mainly consists of a tank for sol-solution, a peristaltic pump, a vibrating nozzle to produce the spherical drops form in ammonia free sector and gelation column where it is contained in ammonia gas and solution respectively. It was constructed to replace test tube experiment scale. The capacity of tank filled sol-solution was $150 \mathrm{~mL}$ and it took 3 hours for dispersing continuous operation and others processes. Ageing and washing process are separated from unified machine. In measuring spherecity we used to measure randomly. In this paper, a wet chemistry step in preparing ADUN and solsolution, continuous dropping formation, gelation reaction, ageing and washing processwill be discussed meanwhile densification of ADU gels through thermal treatment step will be discussed somewhere else.

\section{EXPERIMENTAL METHODS}

Pure uranyl nitrate, uranium in $\mathrm{U}_{3} \mathrm{O}_{8}$ and $\mathrm{UO}_{3}$ (PSTA $=$ Center for Accelerator Science and Technology) PVA MW 72.000 (Merck) and PVA MW 89.000 - 98.000 (Aldrich), $\mathrm{HNO}_{3}$ (Merck), THFA (Merck) Isopropyl Alcohol (Merck), Ammonia Solution (Merck).

\section{Preparation of ADUN (Acid Deficient Uranyl Nitrate)}

Pure uranyl nitrate found from extraction process or triuranium octoxide $\mathrm{U}_{3} \mathrm{O}_{8}$ powder was dissolved in nitric acid, both produc euranyl nitrate (UN) solution in high concentration. Davys Gray method was used to determine and it was found uranium concentration was $600 \mathrm{~g} / \mathrm{L}$ and it was used as a stock solution. ADUN solution was prepared by pre-neutralization reaction. Certain volume of ammonia solution was added to $50 \mathrm{~mL}$ of uranyl nitrate of stock solution drop by drop and should be stopped shortly before ADU precipitation comes out.

\section{Preparation of sol solution}

A sol-solution was prepared by mixing $50 \mathrm{~mL}$ of ADUN solution above with varying amount organic polymer polyvinyl alcohol (PVA) which is a white and granularis soluble in hot water and $2 \mathrm{~mL}$ 
Tetrahydrofurfuryl Alcohol (THFA) at temperature above $70^{\circ} \mathrm{C}$ for 2 hours. Mixture above solution is called sol-solution.

\section{Drop formation}

Sol-solution was pumped by peristaltic pump into a single vibrating nozzle, after being pumped at the exit of nozzle at ammonia free sector, drops fall to pass the ammonia gas sector where surface gelationreaction took place in a bat of an eye. Crust of the drops had been hardened byskinny layer ammonium diuranate.

\section{Gelation}

When surface-hardened drops enter to the ammonia solution, gelation reaction between ammonia solution and uranyl nitrate in internal of drops took place in mantle and core of drops.

\section{Ageing process}

To avoid abnormality of drops on the storage vessel in gelation column, "green" ADU gels are collected into ageing process where gelation process is completed in a vessel containing ammonia solution $7 \mathrm{M}$ on the shakerfor 1 hour.

\section{Washing process}

Additives such as PVA, THFA and by products of gelation reaction $\mathrm{NH}_{4} \mathrm{NO}_{3}, \mathrm{H}_{2} \mathrm{O}$ should be taken out from ADU gels because they are counter productive for further reaction. Both of them are cut out when washing process with Isopropyl Alcohol (IPA) was carried out, while PVA and THFA areeleminated when heating treatment will be done.

\section{Measuring radius}

Samples of some microspheres ADU gels were put in a horizontal plate and in $2 \mathrm{D}$ picture was taken by adigital regular camera. Diameter of ADU gels, make easy complex measurement of sphericity were measured by user-friendly software embedded in digital camera. The simplified flow chart of thegelation process is shown in Fig. 1.

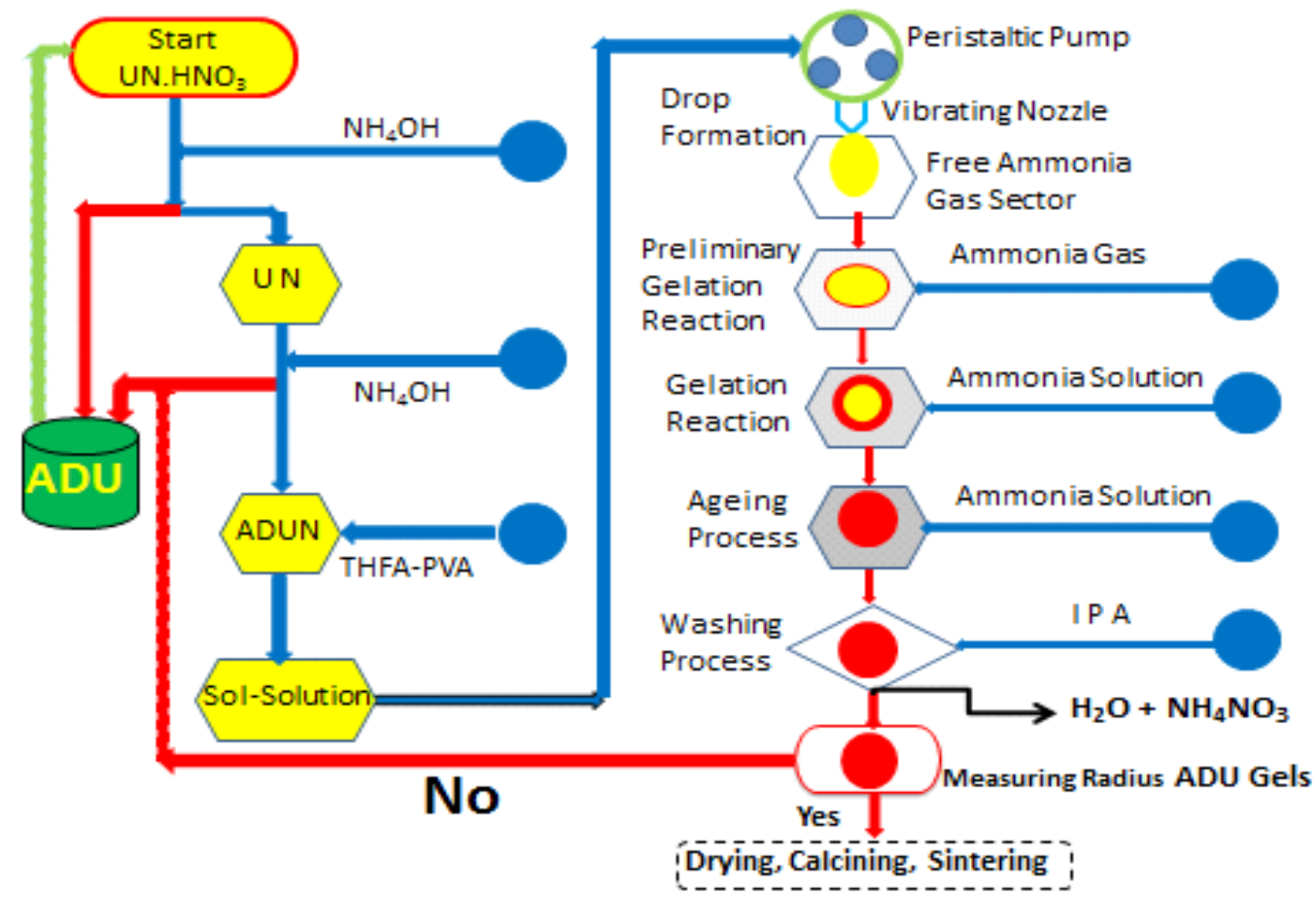

Fig. 1. The simplified flow chart of the gelation process. Yellow circle is sol-solution, red line and red circle are ADU 


\section{RESULT AND DISCUSSION}

Two fundamental parameters of ADUN solution which influence in sol-gel process for ADU gel manufacturing are how high the uranium concentration and molar ratio value of $\mathrm{NO}_{3} / \mathrm{UO}_{2}{ }^{[2]}$. Particular attention should be paid to free nitric acid when UN solution was prepared. Since ADUN solution is prepared from UN solution which has high concentration and undoubt edly it accompanied by free nitric acid. ADUN preparation by pre-neutralization method of UN has two-stages of chemical reaction. First stage is to omit or reduce free nitric acid in UN solution, ammonia solution is gently added to UN solution at room temperature, nitric acid and ammonia reacts first, the reaction can be written as

$\mathrm{HNO}_{3}+\mathrm{NH}_{4} \mathrm{OH} \mathrm{NH} \mathrm{NO}_{3}+\mathrm{H}_{2} \mathrm{O}$

Soon after eradication free nitric acid reaction, it is found that UN solution has molar ratio value $\mathrm{NO}_{3} / \mathrm{UO}_{2}=2$. When ammonia solution was continuously added, the second stageof chemical reaction had taken place. A part of nitric ion of UN was replaced by hydroxide ion. It brings about ADUN solution and the reaction can be written as,

$\mathrm{UO}_{2}\left(\mathrm{NO}_{3}\right)_{2}+\mathrm{x} \mathrm{NH}_{4} \mathrm{OHUO}{ }_{2}\left(\mathrm{NO}_{3}\right)_{2-x}(\mathrm{OH})_{x+}$ $\mathrm{xNH}_{4} \mathrm{NO}_{3}$

where $0 \leq x \leq 1$. Addition of $\mathrm{NH}_{4} \mathrm{OH}$ solution should be stopped shortly before ADU precipitation comes out. ADU used to be $\left(\mathrm{NH}_{4}\right)_{2} \mathrm{U}_{2} \mathrm{O}_{7}$ and new formula of ADU is $x \mathrm{UO}_{3} \cdot \mathrm{y}\left(\mathrm{NH}_{3}\right) \cdot z\left(\mathrm{H}_{2} \mathrm{O}\right)^{[3,4,5]}$. It must have taken lot of experiments to practice makes perfect ADUN solution. The second pre-request for ADUN is molar ratio value $\mathrm{NO}_{3} / \mathrm{UO}_{2}$ less than 2. As mentioned above, when ammonia solution is speedily added to UN solution, ADU in powder form will come out immediately[5]. Unfortunately this route is not appropriate for $\mathrm{UO}_{2}$ kernel production for HTGR fuel. It demands special uranium solution which can be converted into thousands of spherical drops form as shown in Fig. 2.

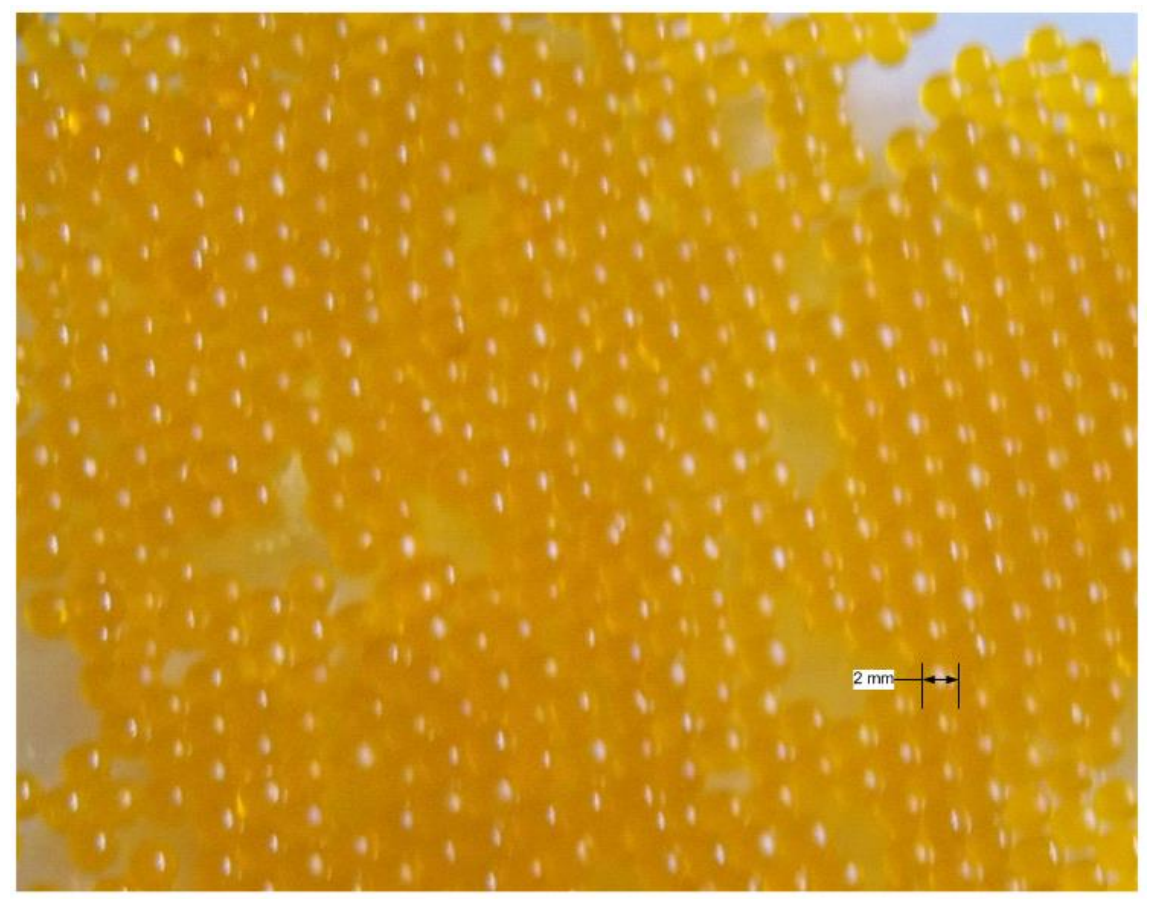

Fig.2. Hundreds of ADU gels found from simple unified homemade machine after, ageing and washing process 
In addition, HTGR fuel density is close to theoretical density of 10.9 , this is a vital requirement[6]. The recognized ADUN solution is used as a precursor solution. ADUN solution is added a water soluble PVA and THFA solution which is heated to $70^{\circ} \mathrm{C}$ $90^{\circ} \mathrm{C}$ for 1 hour using magnetic stirrer in hot plate until homogeneous. Both organics materials above alter the rheological (viscosity and surface tension) properties of the sol-solution in order to produce spherical uniform drops form. It is a major challenge for producing uniformity of drops form, otherwise drops resulted are not uniform. Therefore, it took 2-3 hours to mix sol-solution before dropping experiment is conducted. Viscosity of sol-solution was measured by a rotational viscometer Brookfield DV-E when the temperature of sol-solution was $25^{\circ} \mathrm{C}$. The viscosity of the sol-solution can fluctuate from low to high viscosity, $250 \mathrm{cP}$ to $300 \mathrm{cP}$. Solsolution tank was directly connected to peristaltic pump and the whole system is constructed of wrought a single vibrating nozzle of micro diameter, between $500 \mu \mathrm{m}$ $600 \mu \mathrm{m}$. In order to produce highly automatic and reproduced spherical drops form, all solsolution in the tank was shaped into enormous spherical drops from at the tip of a single vibrating nozzle. This is one of the important demanding steps. In an ideal experiment, profile of drops which grow from drops formation of sol-solution should be in spherical form and it is still in spherical form in gelation column, ageing and washing process as well. Drops are formed in ammonia free sector, when pendant drops at the tip of vibrating nozzle has maximum weight, suitable vibrator frequency gets rid of it easily. The growth and detachability of drops at the tip of vibrating nozzle are heavily influenced by vibrator frequency and amplitude, therefore, their stability and match frequencies are important requirement ${ }^{7,8]}$. Primary ejected drops will come down through gelation column where ammonia gas was purposely flowed and the ammonia solution to get uniform spherical drop of ADU gels. However, the ammonia gas flow meter and vibrator frequency were not easy to be calibrated and operated. Both of them have not been well mastered yet. It is essentially, in each experiment, we simplified over all calibration procedure by measuring number of drops which are in steady-state operation. It was found the rate of drops production 120 - 130 drops each minute. In our experiments, several trials have been conducted, drops found are mixture of spherical, oblate and prolate spheroid shape or in larger part they were imperfect spheroid shapesas shown on Fig. 3.
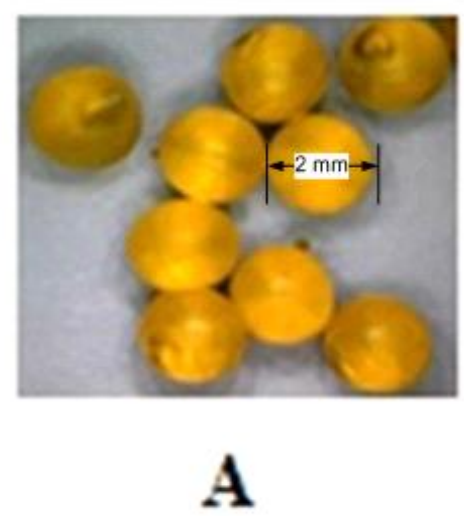

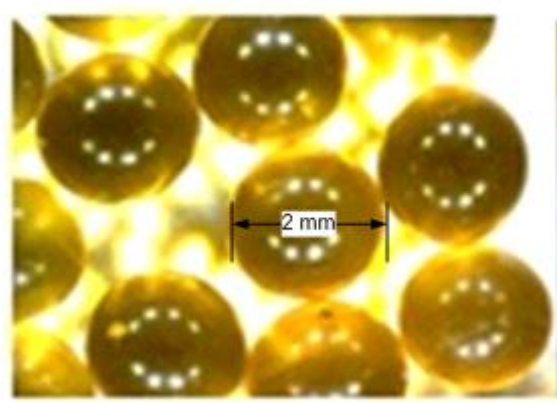

B
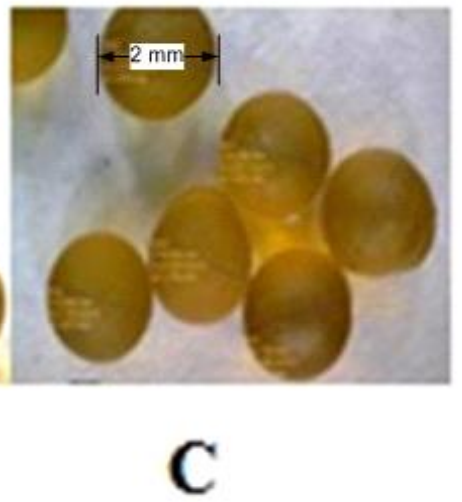

Fig.3. ADU gels found are mixture of spherical, oblate and prolate spheroid shape from three difference experiments ( $A, B, C$ fresh ADU gel) 
Unsuccessful shapes of sol-solution drops into adequate drops in ADU gels form because combine effort of a number parameters such as viscosity, surface tension and density of sol-solution, vibrator frequency-amplitude, flow rate of ammonia gas, the travel length of drops before colliding ammonia surface in gelation column have not been governed well. Furthermore, it was totally difficult to examine the size of drop by naked eyes, it needs digital image processing technology in order to determine whether or not drops produced have uniform size ${ }^{[9]}$. Since we have not used digital image processing technology, the size of drops were not measured immediately. ADU gels sizes were measured indirectly and randomly by use of digital regular camera after washing process. Physical incompleteness of ADU gels, containing huge of tiny dimples on the ADU gels surface are not reasonable. Either heterogeneity in size or in non sphericalform of ADU gels found will be unimpressive for further process. Uranyl nitrate on the surface of drops react with ammonia gas, it might be less than 0.1 second. However, it is a grace period. Skinny layer of ADU formed which blanket the drops and are hoped to be stable enough to keep drops when they hitammonia solution surface in gelation column. Based on the our preliminary experiment, if ammonia gas is not flowed or flow rate of ammonia gas is low, ADU gels form found are not spherical or undergo a serious damage. However, by increasing flow rate of ammoniagas, the quality drops shape has increased moderately. Unfortunately, ammonia gas will need larger experiment room to be pleasant and healthy. Ideally, gelation system should be done in a big fume hood, so workers in the lab would not inhale ammonia gas when the experiment was carried out. As mentioned above, enormous drops have been produced and submerged in high concentration ammonia solution after pre-hardened reaction. Actually, reaction between uranyl ion and ammonia solution in gelation column is complicated because uranyl ion in drops are relatively glued by organic materials. Since organic material is porous, ammonia can penetrate skinny crust, mantle and ultimately to the core of drops. Reaction between uranyl ion and ammonia strongly depends on the $\mathrm{pH}$ of the solution. As shown on reaction ${ }^{[2]}$, where ammonia addition was purposely limited, on a part of nitrate was replaced by hydroxide ion. In gelation reaction between ammonia excess and uranyl ion of the drops which is limited entrance. Therefore, based on $\mathrm{pH}$ of the drops which is not homogenous during gelation and ageing process. Chemically reaction between uranyl ion in mantle and core of drops can be divided into three stages, they are ${ }^{[0]}$

$\mathrm{UO}_{2}\left(\mathrm{NO}_{3}\right)_{2}+\mathrm{NH}_{4} \mathrm{OH} \cup \mathrm{O}_{2} \mathrm{NO}_{3} \mathrm{OH}+\mathrm{NH}_{4} \mathrm{NO}_{3}$

$\mathrm{UO}_{2} \mathrm{NO}_{3} \mathrm{OH}+\mathrm{NH}_{4} \mathrm{OH} \mathrm{UO}(\mathrm{OH})_{2}+\mathrm{NH}_{4} \mathrm{NO}_{3}$

$2 \mathrm{UO}_{2}(\mathrm{OH})_{2}+2 \mathrm{NH}_{4} \mathrm{OH}\left(\mathrm{U}_{2} \mathrm{O}_{7}\right)\left(\mathrm{NH}_{4}\right)_{2}+\mathrm{H}_{2} \mathrm{O}$ or $\mathrm{xUO}_{3} \cdot \mathrm{y}\left(\mathrm{NH}_{3}\right) \cdot \mathrm{z}\left(\mathrm{H}_{2} \mathrm{O}\right)$

Based on the layer of drops reaction between uranyl ion and ammonia solution has three stages, first stage is simpleston the skinny crust of the dropsand in a bat an eye, therefore theamount of ADU formed can be negligible. The second stage, uranyl ion of drops reacts with ammonia solution gelation column, ADU is formed in mantle and core of drops.If reaction between uranyl ion and ammonia solution in gelation column might not be completed, ageing reaction between uranyl ion and ammonia solution is unavoidable. "Green" ADU gels from gelation column had been submerged in ammonia solution $7 \mathrm{M}$ and had been shaken for 1 hour. After ageing process all uranyl ion of drops have presumably reacted with ammonia. ADU gels in drops form will be dense, if uranyl ion in drops is in massive distribution, contrastingly, if uranyl ion of the drops is just in natural and simple distribution, therefore ADU in drops will be less dense. Moreover, the effect of spherical form of drops were investigated at variation uranyl ion distribution throughout a series above reaction. When drops of uranyl ion which has massive distribution will give rise spherical 
ADU gel form after washing process oppositely when drops of uranyl ion which has natural and simple distribution will bring about non spherical ADU gel because organic materials is going to be labile and is due to lack of ADUN preparation and experimental difficulties. All organic materials which are not useful for the next process can be eliminated by thermal treatment. Chemically and physically, ADU gels free of by product $\mathrm{H}_{2} \mathrm{O}$ and $\mathrm{NH}_{4} \mathrm{NO}_{3}$, their quantity is enormous and their form are spherical which have diameter between $1.8 \mathrm{~mm}-2,2$ as shown in Fig. 4.

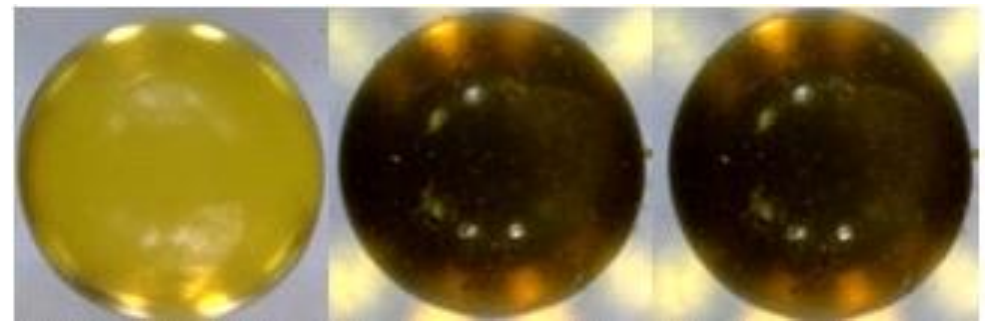

Fig.4. Spherical ADU gels which has diameter between $1.8 \mathrm{~mm}$ and $2.2 \mathrm{~mm}$ from three different experiments (Left, Middle and Right have different diameter)

However, by product in reaction (1) and (2) above, gelation reaction in column and ageing reaction also creates by products $\mathrm{NH}_{4} \mathrm{NO}_{3}$ and $\mathrm{H}_{2} \mathrm{O}$, all by products in entire of drops should be taken out because both of them are undesirable for further process. Existence of $\mathrm{H}_{2} \mathrm{O}$ and $\mathrm{NH}_{4} \mathrm{NO}_{3}$ in ADUN solution and by products in gelation and ageing reaction will be a major drawback for the next process. Neither $\mathrm{H}_{2} \mathrm{O}$ nor $\mathrm{NH}_{4} \mathrm{NO}_{3}$ will be idle in ADU gels. Both by product in ADU gels are necessitated to wash with isopropyl alcohol $90 \%$ three times which were conducted in separated process from the main machine. Both by product will be removed by IPA solution. Therefore, washing process is also very important in this series of physic chemical reaction. Spherical form of microsphere ADU gels were measured by measuring the longest and the shortest diameter of $2 \mathrm{D}$ circle projection which captured by digital camera. Gels diameter in spherical spheroid form found between 1.8 $\mathrm{mm}$ until $2.2 \mathrm{~mm}$. The ADU gels spherical purity was found $10 \%-20 \%$ others are oblate, prolate spheroid and microsphere which have huge tiny of dimples on the surface.

\section{CONCLUSION}

Formation of ADU granular is easily done, however production of microsphere ADU gels which are in spherical spheroid form and have high density arechallenging and very important. Preparation of precursor ADUN solution and a series of ammonia penetration followed by taken out by products have been demanding and complex. We have already successfully created thousands of microsphere ADU gels for each experiment through an automatic machine which have already been constructed. Unfortunately, solsolution preparation, ageing and washing process are still separated from the main machine. Incompleteness of microsphere ADU gels form due to the imperfect physical form of drops forming processand porous of the drops. Sufferable quality production of the drops form and porous of the drops in gelation reaction brings about imperfect microsphere ADU gels form either chemically or physically. Even though, reaction between uranyl ion and ammonia solution chemically have three steps and in three layers in each drops but reaction rate is fast. Based on the uranium concentration, actually, high uranyl ion concentration in ADUN will bring about to have ideal or close to ideal spherical ADU 
gels and sufficient uranium concentration will bring about nonspherical ADU gels. Therefore, high uranyl ion concentration is an imperative and molar ratio of $\mathrm{NO}_{3} / \mathrm{UO}_{2}$ in ADUN solution should be closed to 1,5 in addition, it will be order to have less by product $\mathrm{NH}_{4} \mathrm{NO}_{3}$ and $\mathrm{H}_{2} \mathrm{O}$ in drops when gelation and ageing process took place. Less by product will be declined duty of washing process. Our results show that in each experiment, microsphere of ADU gels is mixture of spherical, oblate and prolate spherical spheroid. On the other hand, spherical purity test was carried out with in 2 D simple digital camera which is limited capability in measuring sphericity of microsphere of ADU gels. This is a major draw backof this experiment. We need special device which can separate spherical spheroid from oblate and prolate spherical spheroid because they have to be separated physically. Microsphere ADU gels which have already in spherical spheroid can go to further process such as drying, calcining, sintering process.

\section{ACKNOWLEDGMENT}

The authors would like to thank to our co-workers who help us in preparation of the samples, our experiments, evaluation and suggestion for better experiments, they are Bambang Pratikno, Endang Nawangsih, Mudjari, Rohyanto, Sri Widyati and Supardjono Mudjiman. The authors would also like to thank the National Nuclear Energy Agency for the financial support.

\section{REFERENCES}

[1] Damunir and Sigit, (2008), Influence of Uranium, PVA, THFA on Kernel Quality Uranium Oxide, Proceedings of Meetings and Scientific Presentation of Basic Science and Nuclear Technology) p 1138 - 144 (In Indonesia).

[2] S. Hao., J. Ma., X. Zhao., Y. Wang., X. Zhou and C. Deng, (2014), Jounal of
Nuclear Engineering and Design 271 p.158-161.

[3] Anonymous, (2012), Experiences and Trens of Manufacturing Technology of Advanced Nuclear Fuels., IAEATECDOC - 1686.

[4] S.Manna, S.B. Roy and J.B. Joshi, (2014), Journal of Nuclear Materials 424 p. 94-100.

[5] Zhou Xiangwen et al, (2012), Journal of Nuclear Engeenering and Design 250 p.192.

[6] A. L.Smirnov et al, (2012), Journal of Hydrometalurgy 127-128 p. $112-115$.

[7] J.A. Phillips, S.G. Nagley and E.L. Shabera, (2012), Journal of Nuclear Engineering and Design 251 p.261281.

[8] D.R. Webster and E.K. Longmire, (2001), Jet Pinch-off and Drop Formation in Immiscible Liquid-Liquid Systems., Journal of Experiments in Fluids 30 p. 47-56.

[9] R.D. Hunt et al, (2014), Journal of Annals of Nuclear Energy 69 p.139 143.

[10] Anonymous, (2014), Investigation on the Conversion of the Final Uranium Concentrate, https://www.google.co.id/?gws_rd=cr,ss I\&ei=xJkSVMyoGoyuAStt4HQAQ\#q=Investigation+on+the +conversion+of+the+final+uranium+con centrate+pdf\&start=20. 